\title{
The Prevention of Victim Precipitation in the Criminal Acts of Fornication and Coition Against Children
}

\author{
Rani Hendriana ${ }^{1 *}$ \\ ${ }^{1}$ Faculty of Law, University of Jenderal Soedirman, Purwokerto, Indonesia
}

\begin{abstract}
All this time, a second victimization in a criminal justice system is considered to be an identical problem for the victims of crime. Thus, it is fair if the whole assessment is more oriented to the legal protection for the victims, especially the child victims in the crime of fornication and coition. However, when viewed from different sides, the source of error is not always absolute to the perpetrator but also because of the victim precipitation. This study examines the victim precipitation and its prevention with the aim to understand the degree of victim precipitation and the proportional prevention, that is not only from the aspect of the perpetrators but also from the aspect of the child victim and the community who have the potential to become victims. This research was conducted in the jurisdiction of Purwokerto City and Banyumas Regency, using sociological juridical research and qualitative research approach. The results show that there are several forms of victim precipitation in the crime of sexual fornication and coition to the child. Meanwhile, the prevention must be conducted comprehensively, either from the internal of the victim, or externally from various related parties.
\end{abstract}

\section{Introduction and Literature Review}

Crime victims are parties who suffer physical, psychological and material losses when a crime occurs. However, legal protection for victims of crime is not proportional to the legal protection of perpetrators [1]. Speaking of victims and the criminal justice system, Doerner [2] stated that

"Those in the criminal justice system are aware that victims are growing increasingly disenchanted with the system's wrong. Participation in the criminal justice system often aggravates the victims' losses. At the same time, the system alienates the victim, making him or her feel like an outsider to both the offense and the system processes".

\footnotetext{
* Corresponding author: ranihendriana27@gmail.com
} 
Karmen [3] also commented that

"The consensus among experts is that criminal justice systems do not measure up to expectations. It fails to deliver what it promises. It does not meet the needs of victims as "clients" or as "consumers" of its services".

Based on this, a second victimization in criminal justice system becomes an identical problem for victims of crime. However, the development of criminology and criminal law theories, as well as the practice of the operation of the criminal justice system in several decades, have undergone major changes, especially with regard to the attention of experts, academics and practitioners on the position of victims in the criminal justice process. Greater attention to the position of victims in criminal justice is shown by the production of various legal rules, both at international and national levels, which regulate the issue of protection and guarantee of victims' rights [4]. The development of studies in academia and the development of various laws and regulations have been oriented to the legal protection of victims. The presence of experts and observers in the field of victims' rights, as well as the formation of Komisi Perlindungan Anak Indonesia (KPAI) and LPSK, is one of the concrete evidences of attention to the victims of crime.

In Indonesia, victims who are currently getting the most attention are children who are victims of criminal acts of fornication and coition. KPAI stated that in 2017, the number of sexual crimes against children reached 116 cases [5]. In the area of Purwokerto City and Banyumas Regency, abuse of children is a concern. However, that is quite alarming, some cases of fornication and coition with children actually occur because of Victim Precipitation. In the Victimology perspective, the occurrence of criminal acts of the perpetrator must not be seen as the only cause, because the victim can also be an element and the cause. Victims who contribute to accelerating the occurrence of criminal acts in a Victimology study are called Victim Precipitation (VP), and here the VP is more focused on understanding the interaction between victims and perpetrators in the occurrence of criminal acts [6].

Children are basically a party that is very at risk of becoming a victim due to having physical and psychological weaknesses, lack of experiences and immature ways of thinking. However, the development of civilization today is able to influence the formation of character and behavior of children to be much more mature, even to the point of causing VP. This is a consequence of the imbalance of attention to victims, where most parties are more oriented to the legal protection of victims and override studies on VP. This condition should be criticized, given the prevention in the occurrence of VP is an urgent matter in proportional crime prevention and preventive action to prevent the occurrence of victims.

Based on this, the formulation of the problems that will be discussed in this article are: First, how victim precipitation in criminal acts of fornication and coition to the children is. Second, how to prevent victim precipitation in criminal acts of fornication and coition to the children are.

\section{Objectives of the Study}

This research was conducted to determine and to analyse the occurrence of victim precipitation in criminal acts of fornication and coition to the children, and the prevention of victim precipitation in the aforementioned criminal act. 


\section{Methodology}

The research methodology used was a qualitative method, with a social legal research approach. The research location is located in Purwokerto City and Banyumas Regency, with research informants include judges, prosecutors, and lawyers in the jurisdiction of Purwokerto City and Banyumas Regency, which were determined by purposive sampling. Primary data was obtained by interview and observation, and secondary data was obtained from literature study. Qualitative data analysis was done by means of content analysis and constant comparative analysis.

\section{Discussion}

\subsection{Victim Precipitation in the Criminal Act of Fornication and Coition to the Children}

Soesilo [7] gives a definition of lewd acts as all actions that violate decency (politeness) or cruel deeds, all of them in the environment of sexual lust. For example, kissing, groping genitals, groping breasts and so on, including in the lewd acts are coition. Whereas coition is defined as a combination of male and female genitals that are usually carried out to get a child, where male genital must enter the female genital. Referring to this, coition has a narrower meaning than sexual abuse. Crimes of sexual abuse against children or immature persons are regulated in Articles 290, 293, 294, 295 of the Criminal Code (KUHP), and Article 76 E and Article 82 of Law No. 35 of 2014 concerning Amendments to Law No. 23 of 2002 concerning Child Protection. The act of coition with children is regulated in Article 287 of the Criminal Code, and Article 76 D and Article 81 of Law No. 35 of 2014.

The definition of children as stipulated in Law No. 35 of 2014 is someone who is not yet 18 years old, including children who are still in the womb. Referring to the limit of child's age, it is natural that the weaknesses inherent in the child make him/her at risk of becoming a victim. But in fact, in the occurrence of several criminal acts of fornication and coition with children, it actually occurs because of VP. Based on the results of interviews with judges, prosecutors and lawyers in Purwokerto City, the most dominant VP occurred precisely in criminal acts of sexual abuse and child copulation.

Some references state that VP is a criminology theory that analyzes how interactions between victims and perpetrators might contribute to the occurrence of a crime. But there is a fundamental difference here, where VP is more focused on understanding the interaction between the victim and the perpetrator for the occurrence of a crime, not on the intent of the perpetrator of committing a crime [6].

This does not mean a blamming victim, but in investigating the causes of someone being a victim of a crime must be seen proportionally and based on the principle of presumption of innocence. In connection with the VP, according to the Prosecutor, that in Purwokerto City, the occurrence of criminal acts of immorality such as fornication and coition with children usually begins with a prior interaction between the victim and the perpetrator. According to him, the behavior and character of the victim can bring the image of the victim's personality which is then captured by the perpetrator as an opportunity, so that the perpetrator considers that the child is willing to have an intimate relationship with him. On the other hand, there are also victims who play an active role in the occurrence of the crime. While the other is the opportunity, namely the place and the possible situation.

The same thing was revealed by several Judges, that the victim who was a child was easily persuaded by the promises of the perpetrator, so she was willing to be molested. There are even cases where victims play an active role in the occurrence of coition, by 
directing the perpetrators to a certain area until they arrive at the hotel and eventually intercourse occurs. The victims in this case asked for compensation from the perpetrators, but the thing that was quite alarming was that it was just revealed in court that the victim had previously had a similar case in other jurisdictions.

It was also revealed by a Prosecutor, that in Banyumas District, in some cases, the perpetrators with the victims had known each other, and previously, the victims had often intercourse with other men. So, the victim is not afraid anymore when intercourse with the perpetrator, and the post mortem evidence shows that the wound on the victim's intimate organ is an old wound. Reinforced by several Advocates' opinions, that in some cases the occurrence of criminal acts of fornication and coition with children cannot be separated from the existence of VP. However, when the act is known by the victim's parents, there is a tendency for victims to say that they have been forced, persuaded, and given liquor by the perpetrators.

On the other hand, according to one Judge, the wrong association caused the victim to be easily persuaded and forced to drink alcoholic beverages, resulting in sexual abuse without the victim's will. Responding to this, the perpetrator is indeed worthy of being blamed. But what needs to be considered is the victims as above, where factually, the victims are in voluntary conditions, not under coercion, even the victims play an active role in moving the perpetrators into sexual abuse, fornication and coition.

Even though the existence of VP can be a factor that alleviates the demands or penalties for the perpetrator, no matter how much the VP contributes to the occurrence of fornication and coition with the child, the perpetrator is still convicted. It also becomes a dilemmatic thing when the perpetrator is also a child, while VP is the biggest contribution in the occurrence of the crime, so that it does not seem to bring justice to the perpetrator. It must be admitted that this is a form of appreciation for children's human rights and legal protection for children who are victims. It must be realized that there is another dangerous side to this. If the legal protection attached to a child victim is not offset by the prevention of the emergence of VP, then the victim can become a victim the second time, and can even be misused for certain purposes. In Banyumas Regency, with regard to women and children who are victims of human trafficking, this is a matter of concern, that the main factor that tends to influence, is the correlation between the victim's fault in the occurrence of human trafficking and the victim's response to legal protection.

The victim does not feel harmed so it is hardly possible if the victim would reveal the case or fight for the right to get the legal protection. The mentality of the victim is hard to be developed, uncooperative, and highly potential to be a permanent victim, which means that he/she will be the victim of human trafficking [8]. Reflecting on this, without the prevention of VP in criminal acts of fornication and coition, the countermeasures will not run proportionally and will be biased.

\subsection{Prevention of Victim Precipitation in Crimes of Fornication and Coition against Children}

The crime prevention strategy can be carried out more proportionally, not only by considering the perpetrators of the crime but also by considering the victims of crime [9]. In connection with the prevention of the occurrence of VP in the occurrence of criminal acts of fornication and coition with children, it is necessary to strengthen the component aspects of legal structure and legal culture.

It is inevitable that the development of civilization in the era of globalization is enough to influence the formation of children's character, so that the synergy between legal structures in the prevention of VP is necessary. However, the efforts made still seem partial 
and not optimal. This is indicated by (1) the lack of preventive measures in the form of socialization of adolescent children carried out by parties with capacity or authority, i.e., police, local/central government, integrated services, social services (2) psycho-social rehabilitation and guidance on the internalization of victims has not been done thoroughly, (3) pornographic sites can still be accessed, and (4) there are no equal perspectives and decisive actions between the regional government, law enforcement officials and hotel/lodging related to the minimum age limit a person can check in. However good the legal substance that has been regulated, without strengthening the commitment and concrete attitude of the legal structure, will certainly be useless.

The prevention of VP also needs to be done by building a comprehensive legal culture, starting from the family, school and community environment. Legal culture in the family becomes a strategic tool in shaping and controlling the character of children at the same time. However, in fact, parents educate their children only oriented to academic education, not mental education and social problems faced by their children. It is noted that $60 \%$ of parents in Indonesia only ask questions about academic education, such as grades, grades in class, and only $30 \%$ percent ask about their social problems, hobbies, problems with friends, social media status, even reproductive problems [10]. Even though children in adolescence already have physical resilience and more mature logic, the search for selfidentity, lifestyle, ability and freedom to access cyberspace and social media, actually increases the vulnerability of victim precipitation.

School is a second home for children after family and most of the children's time is spent in school, so schools have an important role in preventing VP in criminal acts of fornication and coition. However, there are still many schools that choose not to intervene against their students who are dating. The internalization of VP prevention with nuances of immorality is also not something that is easily done by the school, where the child's age is a factor of consideration whether or not internalization is necessary. In connection with the wider community, there is a tendency for people to take part in controlling, which is indicated by raids, community reactive attitudes, and even vigilantism in the case of immoral acts in their environment. It's just that some people still give negative labeling and blaming victims to child victims, and on the other hand are apathetic in providing social rehabilitation to child victims.

\section{Conclusion}

No matter how much the VP contributes to the occurrence of fornication and coition with children, the perpetrator is still convicted. This is a form of appreciation for children's human rights and legal protection for children who are victims. But if it is not balanced with the prevention of the emergence of VP, then the victim can become a victim for the second time, and can even be misused for certain purposes. It's just that prevention of VP in criminal acts of children fornication and coition is still not optimal, especially in aspects of commitment, concrete attitudes and synergy between legal structures. The legal culture aspect, both in the family, school and community circles also seems to have not fully supported the internalization and control of VP prevention in children. 


\section{References}

1. R. Yulia, Jurnal Mimbar Hukum 28(1), 33 (2016)

2. W. G. Doerner, S. P. Lab, Victimology second edition (Anderson Publishing co., Ohio, 1988)

3. A. Karmen, Crime Victims (Cengage Learning, Monteray, 1984)

4. A. H. Samendawai, Jurnal Hukum 16(2), 225 (2009)

5. D. Setiawan, Tahun 2017 KPAI Temukan 116 Perkara Kekerasan Seksual Terhadap Anak (27 September 2017), available from http://www.kpai.go.id/berita/tahun-2017kpai-temukan-116-perkara-kekerasan-seksual-terhadap-anak/, accessed on 7 Desember 2017

6. Angkasa, Simposium Revitalisasi Hukum Nasional dan Pelatihan Hukum Pidana dan Kriminologi Ke-IV, 15-16 (2017)

7. R. Soesilo, KUHP serta Komentar-Komentarnya Lengkap Pasal Demi Pasal (Politeia, Bogor, 1974)

8. R. Hendriana, R. Widyaningsih, D. P. Y. P. Sari, Jurnal Dinamika Hukum 17(3), 281, 285 (2017).

9. Y. Efendi, Pengantar Viktimologi: Rekonsialiasi Korban dan Pelaku Kejahatan (Penerbit Universitas Jenderal Soedirman, Purwokerto, 2001)

10. Liputan 6, KPAI: Pelecehan Seksual Pada Anak Meningkat 100\%, available from http://news.liputan6.com/read/2451254/kpai-pelecehan-seksual-pada-anak-meningkat$\underline{100}$, accessed on 22 November 2016 